\title{
The phenotype characteristics and decline population of Sawang duck in Sawang Village, Karimun Regency, Riau Islands Province
}

\author{
Hidayati*1) $^{1)}$ and Desrita ${ }^{2)}$ \\ ${ }^{1)}$ Animal Science Departement of Agricultural and Animal Science Faculty, Universitas \\ Islam Negeri Sultan Syarif Kasim Riau, Jl. HR. Soebrantas KM 15 Pekanbaru, 28293, Riau, \\ Indonesia, \\ ${ }^{2)}$ Agricultural Extension Center of Kundur Barat District Jl. Bukit Lalang Kundur Village, \\ West Kundur District, Karimun Regency, 29662, Riau Islands Province
}

Submitted: 09 January 2020, Accepted: 03 March 2021

\begin{abstract}
Sawang duck is one of Indonesia's local dual-purpose type ducks due to the offspring of Tsaiya ducks originating from Taiwan. Tsaiya ducks enter the Sawang area, brought by residents from Singapore around 1955 and subsequently bred in the Sawang Village, adapting to the environment and the local farming. This research was conducted in August-December 2018. Primary data on the qualitative, morphometric, and potential feed were taken in Sawang Village, Karimun Regency, Riau Islands Province. Currently, Sawang duck is only found in Sawang Village, kept by two farmers. Secondary data of potential areas and poultry populations were obtained from the Department of Food and Agriculture of Karimun Regency, and proximate analysis was carried out at the Ruminant Nutrition Laboratory, Faculty of Animal Husbandry, Andalas University. The research method was conducted by survey with census sampling techniques. The Sawang duck has a diversity of colors for feather, skin, beak, and shank. The morphometric decrease was indicated by bodyweight of $1,450 \pm 119.52$ grams, femur length of $7.41 \pm 1.62 \mathrm{~cm}$, tibia length of $9.94 \pm$ $0.51 \mathrm{~cm}$, shank length $4.38 \pm 0.25 \mathrm{~cm}$, third finger length $6.36 \pm 0.90 \mathrm{~cm}$, maxilla length 5.21 $\pm 0.16 \mathrm{~cm}$, backbone length $20.13 \pm 1.13 \mathrm{~cm}$, wing bone length $26.65 \pm 1.70 \mathrm{~cm}$, chest bone length $10.63 \pm 0.80 \mathrm{~cm}$, and shank circumference $1.24 \pm 0.10 \mathrm{~cm}$. Efforts to preserve ducks Sawang need to be considered so that their existence is not destroyed by exploiting the existing area's potential.
\end{abstract}

Keywords: Phenotype; Sawang duck; Morphometric; Decline; Population

*Corresponding Author: hidayati@uin-suska.ac.id 


\section{INTRODUCTION}

As a country with a large area, Indonesia has a lot of natural resources and fauna, so it is known as a mega biodiversity country. Ducks are a type of livestock with high diversity that is owned by the Indonesian state; several local duck breeds have been determined through the Minister of Agriculture Certificate, namely Alabio, Bayang, Magelang, Mojosari, Pegagan, Pitalah, Rambon, and Turi duck (Hariyono et al. 2019), as well as Talang Benih duck (Minister of Agriculture Decree Number 2836 / Kpts / LB.430 / 8/2012), Kerinci duck (Minister of Agriculture Decree Number 2834 / Kpts / LB.430 / 8/2012), Tegal duck (Minister of Agriculture Decree Number 2922 / Kpts / OT.140 / 6/2011) and Sawang duck (Department of Animal Husbandry of Riau Province 2003).

Through morphometric and molecular analysis, Indonesian local ducks belong to the Anas platyrchynchos (Mallard duck) group with an average genetic distance ranging from 0,000-0,786 (Purwantini et al., 2013). Even though they are in the same cluster, the diversity of qualitative and quantitative traits in these local ducks is diverse. It forms their characteristics which can be passed on to subsequent offspring. Genetic and morphometric diversity are important for breeding management and increasing productivity of these local ducks (Henrik, Purwantini and Ismoyowati, 2018), design of animal breeding programs, genetic mapping, and molecular markers (Yakubu, Kaankuka and Ugbo, 2011; Rusdin et al., 2020). One of the local duck genetic resources possessed by the Riau Islands Province is Sawang duck (Setioko, Prasetyo and Sinurat. 1998; Departement of Animal Husbandry of Riau Province, 2003).

Sawang duck is thought to originate from Tsaiya duck derivatives from Taiwan brought by resident from Singapore in 1955 (Setioko, Prasetyo, and Sinurat, 1998). The population and productivity of ducks have declined from year to year without special attention from the local government. The number of Sawang duck ownership per breeder in 1998 reported by Setioko, Prasetyo, and Sinurat (1998) was 162 heads, much lower than in previous years, which reached 2.000-3.000 heads per breeder. In 2002, a Sawang duck development program was carried out in Durai Village Karimun Regency by the Department of Animal Husbandry, Karimun Regency. In 20032004 in Buru Village, the program was unsuccessful through the aid of young duck for farmers. Until this research was conducted, there was no recent information regarding the population and phenotype characteristics of Sawang duck in Sawang Village as a center for the development of Sawang duck in the past.

The characteristic phenotypes of Sawang duck are the color of the feather is grayish whites, the color of the shank is blackish gray to yellowish-white, the color of the skin is white, the profile of the body is sturdy and rather large, the beak is flat and yellow, the color of the shell is white. Adult female body weight is greater than the male, reaching $1.6 \mathrm{~kg}$ while only $1.5 \mathrm{~kg}$. The first of egg production is 24 weeks, with egg production ranging from 200-250 eggs per year (Department of Animal Husbandry of Riau Province, 2003). Judging from some of the color body such as grayish-white feathers, yellow shank and beak, its suspected that Sawang duck is the offspring natural marriage between tsaiya ducks and peking ducks that breeders keep praying for the Confucians in Karimun. Based on that, Sawang duck were kept by farmers for dual purposes; eggs and meat production.

The existence of livestock population in an area results from the interaction of several dimensions of the region in the form of technology (production capital), economic and social conditions of the community. These three dimensions interact to form an enabling environment that allows livestock populations to develop (Steinfeld et al. 1997). The efforts to conserve local ducks depend on the degree of suitability and adaptation to the environment, the 
economic characteristics possessed, and the local breed's cultural and historical values (Hariyono et al., 2019). Therefore, optimizing the management of various available resources to ensure environmental sustainability is the first step that can be taken in the business of developing ducks in the future, including through exploration of natural resources and genetic resources of Sawang duck in Sawang Village, Karimun Regency, Riau Islands Province.

\section{MATERIALS AND METHODS}

Data collection on qualitative and morphometric characteristics of Sawang duck and data on natural resource potential was carried out in Sawang Village, Kundur Barat District, Karimun Regency, Riau Islands Province in August 2018. Currently, Sawang duck is only found in Sawang Village, kept by two farmers.

Analysis of feed ingredients was carried out at the Ruminant Nutrition Laboratory, Faculty of Animal Husbandry, Andalas University, Padang, West Sumatera in November - December 2018. The materials used in this study were 8 adult female Sawang duck from 2 breeders in Sawang Village, Karimun Regency, Riau Islands Province. Secondary data were obtained from the Department of Food and Agriculture of Karimun Regency, Riau Islands Province.

This research was a census field survey research by taking regional potential data and data of all ducks kept in Sawang Village, Kundur Barat District, Karimun Regency, Riau Islands Province, as the center for the development of Sawang duck in the past. The parameters in this study were the qualitative phenotypes and morphometric data of the Sawang duck. The qualitative characteristics observed were feather color, skin color, beak color, and shank color. Morphometric data include bodyweight (gram), femur length $(\mathrm{cm})$, tibia length $(\mathrm{cm})$, shank length $(\mathrm{cm})$, third finger length $(\mathrm{cm})$, maxilla length $(\mathrm{cm})$, backbone length $(\mathrm{cm})$, wing bone length $(\mathrm{cm})$, breast bone length $(\mathrm{cm})$ and shank circumference (cm) (Sartika, 2013). Morphometric measurements using calipers and measuring tape. Primary data on regional potential is done by interview technique and direct observation in the field.

\section{RESULT AND DISCUSSION \\ The potential of Sawang Village in Sawang duck development}

Sawang Village is the name of Kundur Barat Subdistrict's capital, which is located on Kundur Island, which is administratively the only sub-district in Kundur Barat Subdistrict. Kundur Island consists of 3 subdistricts, namely Kundur Kota District, West Kundur District, and North Kundur District. West of the island of Kundur is directly bordered by Riau Province, namely Pulau Mendol (Penyalai), Pelalawan Regency. The population of ducks and other poultry in 2017 in Karimun Regency is presented in Table 1. Based on the Karimun Regency Food and Agriculture Service data, the duck population in Karimun Regency is only $0.38 \%$ of the total poultry population. The highest percentage found was laying hens $(48.32 \%)$ and followed by broilers $(44.62 \%)$ and native chickens (6.68\%).

Sawang duck's population in Sawang Village as a center for the development of Sawang duck used to be almost extinct. There are only two breeders left to keep their ducks, namely Muhammad Tadir and Pue Keng. Information from the Department of Food and Agriculture of Karimun Regency decreased Sawang duck population due to the reduced number of rebon (small shrimp) and the high price of feed, not comparable to Sawang meat and eggs' selling price. The survey result in the field found six types of feed commonly used by farmers in preparing Sawang duck rations, namely sago or "serampin" (Figure 1a), rebon or "murbei" (Figure 1b, 1c, 1d), rice bran (Figure 1e), fish head (Figure 1f ), and crushed corn (Figure 1g).

Based on an interview with one of the breeders Muhammad Tadir, the purpose of production determined the formula for Sawang ration. If the purpose of keeping is 
to produce eggs, usually enough given sago and rebon in a ratio of $4: 1$. For meat production, feed ingredients are given more varied than given sago and rebon, added coconut pulp, rice bran, corn, and broiler rations. Sago is given by finely chopping sago stems (Figure 1a) so that the feed's quality is better. Broiler rations are imported from Tanjung Batu while rice bran from Panyalai, Pelalawan Regency, Riau Province. This resulted in the relatively high feed price, not comparable to the selling price, and a decrease in egg production and duck weight.

Table 1. The Population of Poultry in Karimun Regency 2017 year

\begin{tabular}{llcccc}
\hline \multirow{2}{*}{ No } & \multicolumn{1}{c}{ Districts } & Native Chicken & Hen Laying & Poultry Type (heads) \\
\cline { 3 - 6 } & Karimun & 900 & 0 & 14.300 & 23 \\
2 & Kundur Kota & 340 & 92.000 & 29.700 & 200 \\
3 & Meral & 870 & 0 & 20.000 & 100 \\
4 & Tebing & 450 & 0 & 20.000 & 70 \\
5 & Meral Barat & 983 & 0 & 50.000 & 125 \\
6 & Buru & 1.221 & 1.500 & 0 & 350 \\
7 & Kundur Barat & 4.500 & 76.000 & 34.000 & 400 \\
8 & Kundur Utara & 755 & 20.500 & 5.000 & 180 \\
9 & Ungar & 193 & 0 & & 0 \\
10 & Moro & 15.051 & 0 & 2.450 & 0 \\
11 & Durai & 850 & 0 & 0 & 0 \\
12 & Belat & 155 & 0 & 175.450 & 1.475 \\
\hline \multicolumn{7}{r}{} & Total & Percentage & 26.268 & 48,32 & 44,62 & 0,38 \\
\hline
\end{tabular}

Source: Karimun Regency Food and Agriculture Service 2019 (Unpublished)

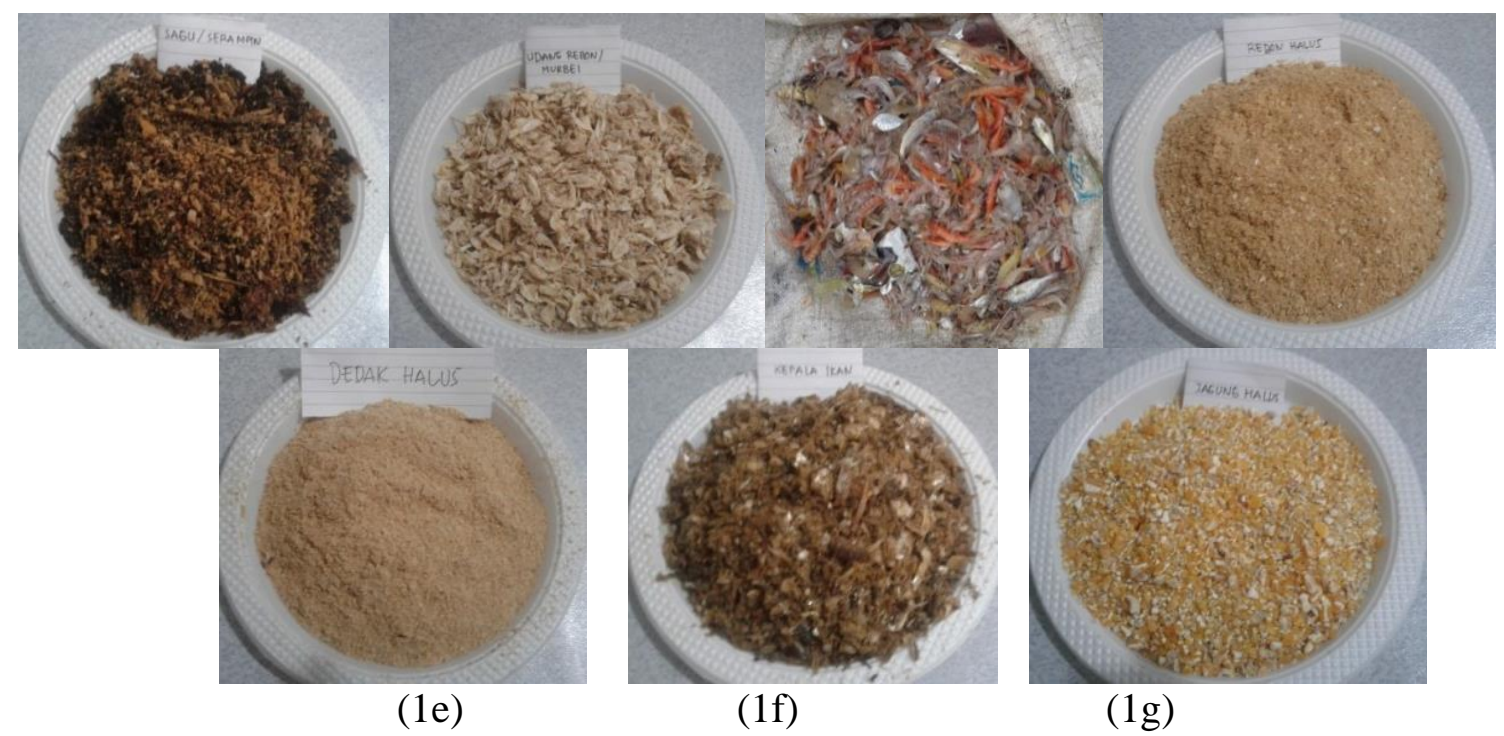

Captiom 1 : (a) sago (b) dried rebon (c) wet rebon (d) smoth rebon (e) rice barn (f) fish head (g) chrushed corn

Figure 1. Duck Feed Found in Sawang Village

The nutritional value of feed ingredients from several types of feed found in Sawang Village, Karimun Regency, Riau Islands Province based on laboratory analysis results was presented in Table 2 . The sago price in the study was Rp. 50,000 /stick, which can be used for 50 ducks in one month. Rebon is obtained from fishermen's catch which is then dried. Rice bran is sold at Rp. $4000 / \mathrm{kg}$, fish head Rp. 10,000/kg, fine shrimp Rp. 8,000 $/ \mathrm{kg}$, crushed corn Rp. 7,500-Rp.8,000/kg, and dried rebon Rp.10,000/kg. The declined Sawang duck population is also due to the selling of duck 
eggs has been difficult because of buyers' turned to cheaper laying hens eggs. In this area, the price of duck eggs is in the range of Rp. 3,000 - Rp. 5,000/egg, depending on egg size, while the price of laying hens eggs in the range Rp. 1,200 - Rp. 1,500/egg.

The declined sawang duck population is also caused by farmers switched Peking ducks because they have greater body weight, faster growth, and higher prices. At the farmer level, the price of adult Sawang duck ranges between Rp.55,000- Rp.60,000 per head. Sawang duck is a dual-purpose type of duck that cannot incubate its eggs. Egg incubation was done mallard (Cairina moschata) or native chicken. The success rate of hatching ranges from $70 \%-80 \%$. Inbreeding causes a decrease in the productivity of sawang duck.

Table 2. Feed Nutrition Content of Ducks Found in Sawang Village, Karimun Regency, Riau Islands Province

\begin{tabular}{lcccccc}
\hline \multirow{2}{*}{ Types of Feed } & \multicolumn{7}{c}{ Nutrition Content (\%) } \\
\cline { 2 - 7 } & WC & DM & CP & CF & CFb & Ash \\
\hline Sago & 2,06 & 97,95 & 6,00 & 1,46 & 11,35 & 1,27 \\
Crusched Corn & 3,56 & 96,43 & 6,30 & 6,40 & 11.53 & 1,91 \\
Rice Barn & 1,44 & 98,55 & 5,59 & 3,53 & 10,82 & 3,53 \\
Dried Rebon & 1,75 & 98,25 & 34,10 & 1,27 & 8,52 & 1,46 \\
Smooth Rebon & 1,25 & 98,75 & 44,54 & 4,39 & 8,66 & 1,00 \\
Fish Head & 2,14 & 97,86 & 50,02 & 1,00 & 6,05 & 4,39 \\
\hline
\end{tabular}

Source: Results of This Research

Note: WC (Water Content), DM (Dry Matter), CP (Crude Protein), CF (Crude Fat), CFb (Crude Fiber).

Farmers sell half of DOD (Day Old Duck) to other farmers and sell good quality ducks due to high selling prices. This resulted in developing ducks that have low genetic quality. Sawang duck farming systems are carried out semi-intensively on traditional cages (Figure 2). Sawang duck was combined with other poultry types such as mallard, native chickens, and other types of ducks (mojosari ducks and peking ducks).

This allowed inbreeding or intermarriage between different breeds or between species. Improving the keeping system also needs to be done to increase productivity and improve genetic quality.

\section{Qualitative characteristics and morphometrics of Sawang duck}

Data on the qualitative characteristics of adult female Sawang duck were presented in Table 3. It was found that the color variability of feathers, beak, shank, neck feather, back, chest, inner wing, outter wing, tail, and thigh (Figure 3). Skin color was showed uniformity white. According to the Department of Animal Husbandry of Riau Province (2003), the color of Sawang duck feathers is grayish-white, the color of the feet is grayish-black to yellowish-white, the color of the skin is white, and the beak is yellow. According to Setioko, Prasetyo, and Sinurat (1998), it was suspected that the Sawang duck came from Tsaiya duck derivatives (Figure 5) from Taiwan brought from Singapore by the local community around 1955.

Characteristics of feather color, necklace lines, skin color, and the color of the tsaiya duck's beak as the ancestors of Sawang duck are still found in Sawang duck. The morphometric diversity of adult female ducks in Sawang Village was presented in Table 4. 

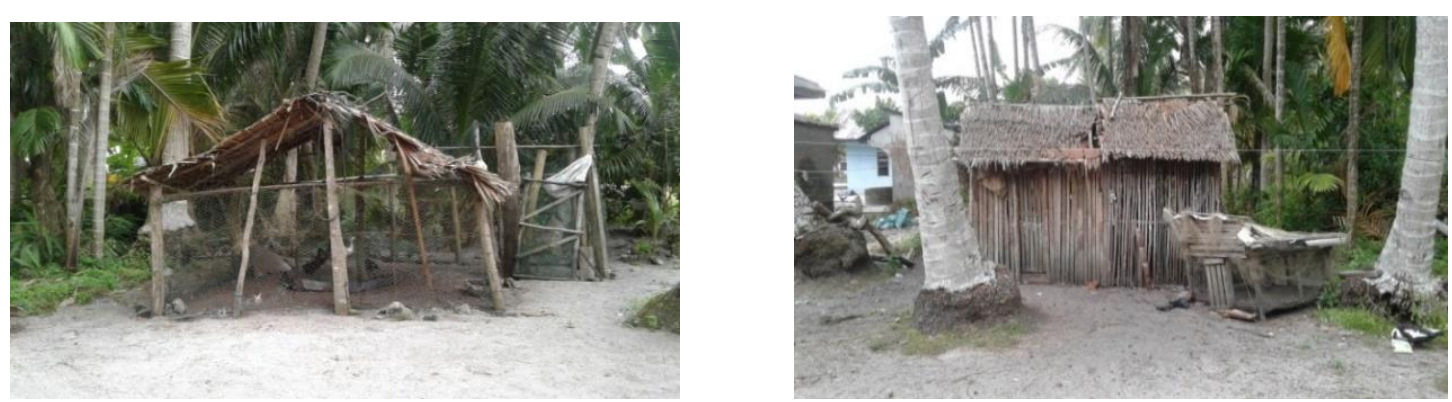

Figure 2. The condition of ducks and poultry cages in Sawang Village
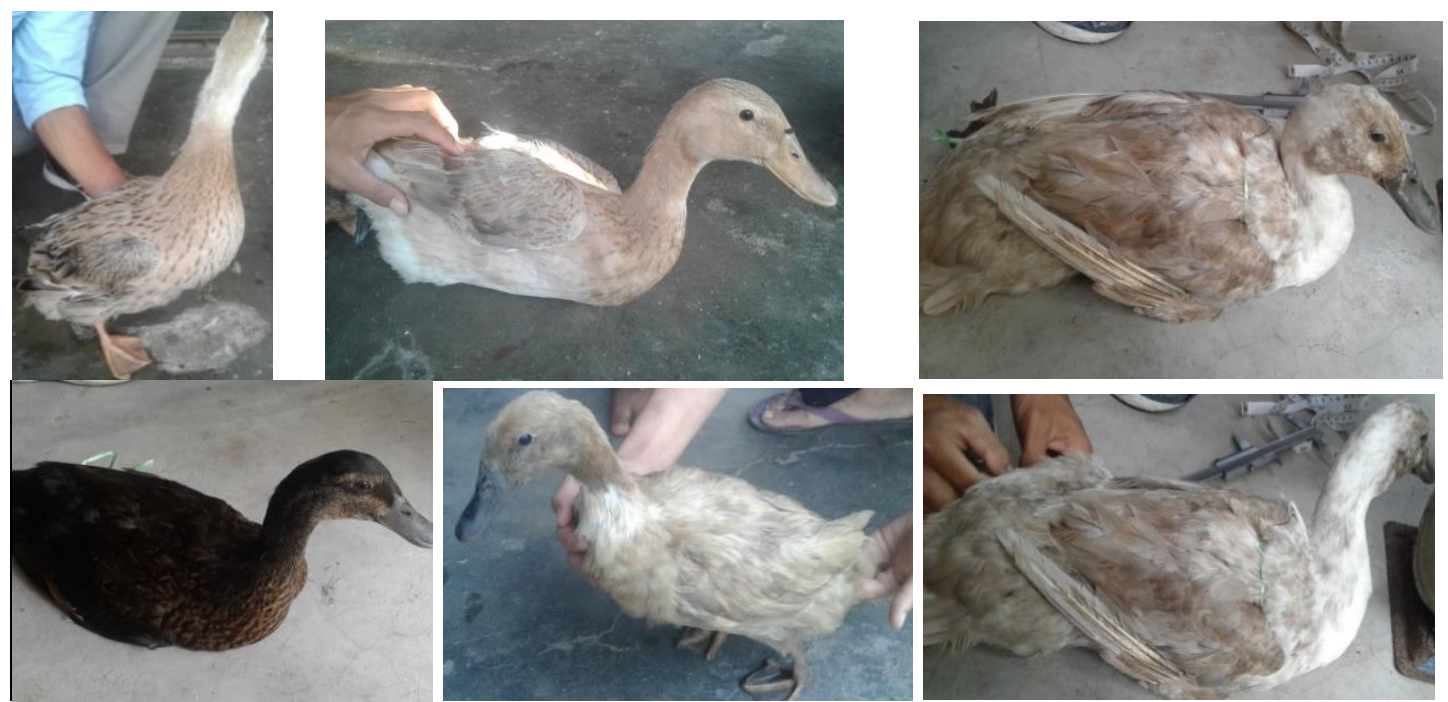

Figure 3. Qualitative Characteristics of Sawang duck

The average body weight of 1,450 grams range from 1,200 grams $-1,600$ grams. This value was lower than the standard of the Sawang breed according to Departement of Animal Husbandry Riau Province (2003), which states that the bodyweight of the adult female Sawang duck is at least 1,600 grams, lower than the Cihetaup duck (Dudi, 2007) and Bali duck (Tarigan et al., 2015).

Farmers did the decrease in body weight of ducks due to inbreeding and or negative selection. Negative selection can be interpreted as farmers' behavior to choose animals that show high body weight for sale rather than for further breeding. The mean of adult female Sawang duck weight was smaller than Manila duck (1,700 gram), Alabio duck (1,800 gram), Bali duck $(1,800$ gram), Tegal duck (1,500 gram), Magelang duck (1500 gram) but higher than Rambon duck $(1,200$ gram $)$ in the same sex
(Hidayati, E. Saleh and B. Kuntoro, 2016). Femur length is the variable with the highest diversity coefficient of $21.91 \%$ and followed the third finger length (14.11\%).

\section{SWOT analysis and development strategy of Sawang duck}

Based on the result of the study, it can be concluded the SWOT analysis (Strengths, Weaknesses, Opportunities, Threats Analysis) in Table 6. Based on the SWOT analysis, several strategies can be prepared that can be done by utilizing all the potential;

a. Increase breeders' knowledge of breeding management

b. Utilizing local food sources other than sago and rebon as compilers of Sawang feed rations through technological innovations through training of ration formulations to farmers. 
Table 3. Qualitative Characteristics of Sawang duck

\begin{tabular}{|c|c|c|c|}
\hline No & Variables & $\%$ & $\mathrm{~N}$ \\
\hline \multirow[t]{4}{*}{ 1. Beak Color } & - Black Grayish & 25,0 & 2 \\
\hline & - Black & 50,0 & 4 \\
\hline & - Yellow Brownish & 12,5 & 1 \\
\hline & - Yellow & 12,5 & 1 \\
\hline 2. Skin Color & White & 100 & 8 \\
\hline \multirow[t]{5}{*}{ 3. Shank Color } & - Black & 37,5 & 3 \\
\hline & - White & 12,5 & 1 \\
\hline & - Yellow Blackis & 12,5 & 1 \\
\hline & - Brown Blackis & 12,5 & 1 \\
\hline & - Red & 25,0 & 2 \\
\hline \multirow[t]{8}{*}{ 4. Neck Color } & - Black Brownish & 12,5 & 1 \\
\hline & - Black & 12,5 & 1 \\
\hline & - Black Greenish & 12,5 & 1 \\
\hline & - White & 12,5 & 1 \\
\hline & - Brown neckles white & 12,5 & 1 \\
\hline & - Yellow brownis & 12,5 & 1 \\
\hline & - Light Brown & 12,5 & 1 \\
\hline & - Brown white & 12,5 & 1 \\
\hline \multirow[t]{5}{*}{ 5. Chest Color } & - Black & 25,0 & 2 \\
\hline & - Brown Black & 12,5 & 1 \\
\hline & - Brown Gray & 25,0 & 2 \\
\hline & - White & 25,0 & 2 \\
\hline & - White Brown & 12,5 & 1 \\
\hline \multirow[t]{5}{*}{ 6. Tail Color } & - Black & 25,0 & 2 \\
\hline & - Black Brown & 25,0 & 2 \\
\hline & - Brown Grayish & 25,0 & 2 \\
\hline & - Brown dark, Light brown, and white & 12,5 & 1 \\
\hline & - Gray & 12,5 & 1 \\
\hline \multirow[t]{5}{*}{ 7. Back Color } & - Black & 25,0 & 2 \\
\hline & - Brown Black & 12,5 & 1 \\
\hline & - Dark Brown & 12,5 & 1 \\
\hline & - Grey Brown & 37,5 & 3 \\
\hline & - White Grey & 12,5 & 1 \\
\hline \multirow{6}{*}{$\begin{array}{l}\text { 8. Outter of } \\
\text { Wing Color }\end{array}$} & - Black Greenish & 12,5 & 1 \\
\hline & - Brown Grey & 37,5 & 3 \\
\hline & - Dark Brown & 12,5 & 1 \\
\hline & - Brown Black White & 12,5 & 1 \\
\hline & - Grey & 12,5 & 1 \\
\hline & - Dark Brown, Light Brown & 12,5 & 1 \\
\hline \multirow{5}{*}{$\begin{array}{l}\text { 9. Inner of } \\
\text { Wing Color }\end{array}$} & - Brown Black & 12,5 & 1 \\
\hline & - Brown Grey & 25 & 2 \\
\hline & - White Grey & 12,5 & 1 \\
\hline & - Grey & 37,5 & 3 \\
\hline & - White & 12,5 & 1 \\
\hline \multirow[t]{6}{*}{ 10. Thigh Color } & - Black & 25,0 & 2 \\
\hline & - Dark Brown & 12,5 & 1 \\
\hline & - Dark Brown, Light Brown, White & 12,5 & 1 \\
\hline & - Brown Grey & 12,5 & 1 \\
\hline & - Grey & 25,0 & 2 \\
\hline & - White & 12,5 & 1 \\
\hline
\end{tabular}


Tabel 4. Body Weight and Morphometric of Sawang Duck

\begin{tabular}{lrrrrr}
\hline \multicolumn{1}{c}{ Variables } & Mean & $\begin{array}{c}\text { Standard } \\
\text { Deviation }\end{array}$ & Maximal & Minimal & $\begin{array}{c}\text { Variabiilty of } \\
\text { Coeficient }(\%)\end{array}$ \\
\hline Body Weight $(\mathrm{g})$ & 1450,00 & 119,52 & 1600,00 & 1200,00 & 8,24 \\
Femur lenght $(\mathrm{cm})$ & 7,41 & 1,62 & 10,50 & 5,60 & 21,91 \\
Tibia lenght $(\mathrm{cm})$ & 9,94 & 0,51 & 10,70 & 9,20 & 5,16 \\
Shank lenght $(\mathrm{cm})$ & 4,38 & 0,25 & 4,90 & 4,10 & 5,70 \\
The Third finger lenght $(\mathrm{cm})$ & 6,36 & 0,90 & 7,90 & 4,80 & 14,11 \\
Maxila lenght $(\mathrm{cm})$ & 5,21 & 0,16 & 5,50 & 5,00 & 3,15 \\
Back bone lenght $(\mathrm{cm})$ & 20,13 & 1,13 & 22,00 & 18,00 & 5,59 \\
Wing bone lenght $(\mathrm{cm})$ & 26,65 & 1,70 & 30,10 & 24,70 & 6,39 \\
Chest bone lenght $(\mathrm{cm})$ & 10,63 & 0,80 & 12,20 & 9,50 & 7,51 \\
Shank circumference $(\mathrm{cm})$ & 1,24 & 0,10 & 1,40 & 1,10 & 7,88 \\
\hline
\end{tabular}

c. Diversification of processed food products based on ducks such as duck nuggets, sausage duck, duck eggs rendang, etc.

d. Expanding the marketing network of duck and its processed products.

e. Providing adequate production facilities and infrastructure assistance to farmers, especially in making cages and hatching machines.

f. Preserve and develop Sawang duck breeding by establishing the Sawang duck (UPT) Technical Services Unit by the government or relevant agencies to produce and provide continuous Day Old Duck for farmers.

g. The Sawang duck development area's concentration is not mixed with other types of ducks, especially other species.

h. Innovating in ration processing based on the available feed potential.

i. Utilization of Artificial Insemination technology to conserve Sawang duck so that the population is not extinct.

j. Establish a conservation area for the development and preservation of Sawang duck.

Table 5. SWOT Analysis of Development and Increasing Productivity of Sawang Duck

\begin{tabular}{|c|c|}
\hline \multicolumn{2}{|c|}{ Internal Factors } \\
\hline Strengths & Weaknesses \\
\hline 1. Have a local duck breed (Sawang duck) that & 1. Declining Sawang duck population \\
\hline has adapted to the local environment & 2. Knowledge farmers about \\
\hline 2. The experience of duck farmers enough long & management are still lacking. \\
\hline time & 3. The availability of rebon and sago as the main \\
\hline 3. Have a potential source of feed & source of feed is difficult to obtain. \\
\hline 4. The extent of land that can be utilized & 4. Cages that are not feasible \\
\hline $\begin{array}{l}\text { 5. The availability of good transportation and } \\
\text { communication facilities }\end{array}$ & $\begin{array}{l}\text { 5. Farmers are not in groups, making } \\
\text { communication difficult. }\end{array}$ \\
\hline 6. The availability of clean water sources & 6. The decreasing genetic quality of Sawang duck \\
\hline $\begin{array}{l}\text { 7. Strategic location for marketing and tourism } \\
\text { areas }\end{array}$ & $\begin{array}{l}\text { 7. The interest of farmers in keeping ducks } \\
\text { Sawang reduced due to the low genetic quality }\end{array}$ \\
\hline 8. Never found a dangerous infectious duck disease & $\begin{array}{l}\text { 8. Lack of knowledge of farmers in making } \\
\text { processed food diversification based on duck }\end{array}$ \\
\hline
\end{tabular}

\section{Opportunities}

1. The selling price of Sawang meat and eggs is high

2. Strategic location, which allows being used as an export commodity

3. Allows the development of Sawang duck business into the main business

\section{External Factors}

1. The entry of other duck breeds that have better productivity, especially for meat growth

2. Objections of the community around the farm due to the foul odor caused

3. Rearing of Sawang duck in one cage mixed with other livestock such as pigs, geese, and ducks

4. Fluctuations of the feed price 


\section{CONCLUSIONS}

The results showed that the Sawang duck's population was almost extinct in Sawang Village, the center for Sawang duck development. Found a diversity of qualitative characteristics of Sawang duck thought to be caused by crossbreeding with another breed of ducks and mallards. Morphometrics decrease in Sawang duck was indicated bodyweight of 1,450 \pm 119.52 grams, femur length of $7.41 \pm 1.62 \mathrm{~cm}$, tibia length of $9.94 \pm 0.51 \mathrm{~cm}$, length of shank $4.38 \pm 0.25 \mathrm{~cm}$, third finger length $6.36 \pm$ $0.90 \mathrm{~cm}$, maxilla length $5.21 \pm 0.16 \mathrm{~cm}$, backbone length $20.13 \pm 1.13 \mathrm{~cm}$, wing bone length $26.65 \pm 1.70 \mathrm{~cm}$, bone length chest $10.63 \pm 0.80 \mathrm{~cm}$, and shank circumference $1.24 \pm 0.10 \mathrm{~cm}$.

Efforts should be made to utilize local resources such as the utilization of local feed, efforts to improve management of kept and breeding, and diversification of processed egg and duck meat products to improve the economy of farmers. It is necessary to preserve and develop ducks by the relevant government agencies so that these ducks' existence was not extinct.

\section{ACKNOWLEDGMENT}

This research is part of a study entitled "Phylogenetic Exploration and Sawang duck Development Strategy as Germplasm of Riau Islands Province" funded by the Research and Community Service Institute of Suska Riau through the Rector's Decree Number: 0936/R/2018 and was presented at the National Seminar Optimizing the Utilization of Potential Local Resources Towards Food Independence To Achieve Sustainable Development Goal's (SDG's) organized by Mahaputra Muhammad Yamin University, Faculty of Agriculture, Solok, West Sumatera on 3-4 September 2019.

\section{REFERENCES}

Departement of Animal Husbandry of Riau Province (2003). Penetapan Standar Bibit Ternak Propinsi Riau.

Dudi. (2007). Identifikasi sifat kuantitatif itik Cihateup sebagai sumberdaya genetik unggas lokal. Jurnal Ilmu Ternak, 7(1), 1-8.

Hariyono, D. N. H., Maharani, D., Cho, S., Manjula, P., Seo, D., Choi, N., Sidadolog, J. H. P., \& Lee, J.-H. (2019). Genetic diversity and phylogenetic relationship analyzed by microsatellite markers in eight Indonesian local duck populations. Asian-Australasian Journal of Animal Sciences, 32(1), 31-37. https://doi. org/10.5713/ajas.18.0055

Henrik, H., Purwantini, D., \& Ismoyowati, I. (2018). Morphometrics and genetic diversity of Tegal, Magelang and their crossbred ducks based on Cytochrome $\mathrm{b}$ gene. Journal of the Indonesian Tropical Animal Agriculture, 43(1), 9-18. https://doi.org/10.14710/jitaa. 43.1.9-18

Hidayati, Saleh, E., \& Kuntoro, B. (2016). Modul Pelatihan Tanda Gotik. Pelatihan Tanda Gotik DIKTIS KEMENAG RI.

Purwantini, D., Yuwanta, T., Hartatik, T., \& Ismoyowati. (2012). Polymorphism of D-Loop mitochondrial DNA region and phylogenetic in five Indonesian native duck population. International Journal of Poultry Science, 12(1), 5563. https://doi.org/10.3923/ijps.2013. 55.63

Rusdin, M., D.D. Solihin, A. Gunawan C. Talib and C. Sumantri. (2020). Genetic variation of eight Indonesian swamp-buffalo populations based on cytochrome $\mathrm{b}$ gene marker. Tropical Animal Science Journal 43(1): 1-10. https://doi.org/10.5398/tasj.2020.43.1 .1.

Sartika, T. (2013). Perbandingan Morfometrik Ukuran Tubuh Ayam KUB dan Sentul Melalui Pendekatam Analisis Diskriman. Seminar Nasional Teknologi Peternakan Dan Veteriner, 561-570.

Setioko, A., Prasetyo, L. H., \& Sinurat, A. P. (1998). Profil Usaha Peternakan Itik Sawang di Kepulauan Riau, Potensi dan Permasalahannya. Seminar 
Nasional Peternakan dan Veteriner, 706-712.

Steinfeld, H., De Haan, C., \& Blackburn, H. (1997). Livestock-Environment Interactions: Issues and options. In European Commission DirectorateGeneral for Development. FAO Working Paper.

Tarigan, H.J, I. Setiawan \& D. Garnida. 2015. Identifikasi Bobot Badan dan Ukuran-ukuran Tubuh Itik Bali. Students e-Journals 4 (2): 1-7

Yakubu, A., F.G, Kaankuka \& S.B. Ugbo. (2011). Morphometric Traits of Muscovy Ducks From Two Agroecological Zones of Nigeria. Tropicultura 29 (2): 121-124. 